\title{
Synthesis and conformational investigation of tetrapeptide analogues of the fragment B23-B26 of insulin
}

\author{
Lígia M. Rodrigues, José I. Fonseca and Hernâni L.S. Maia* \\ Centro de Química, IBQF, University of Minho, 4710-057, Braga, Portugal
}

\begin{abstract}
Tetrapeptides containing one of a set of four different $\alpha, \alpha$-dialkyl glycines at the Cterminus were synthesized by conventional methods in solution and their conformational behavior investigated by ${ }^{1} \mathrm{H}$ NMR spectroscopy in connection with molecular mechanics calculations. The results were consistent with conformations stabilized by a $\gamma$-turn in the case of compounds with alkyl groups larger than methyl, while the corresponding Aib derivative did not exhibit intramolecular hydrogen bonding.
\end{abstract}

\section{Introduction}

Peptides containing one or more residues of an $\alpha, \alpha$-dialkyl glycine are conformationally constrained owing to restriction of their conformational freedom imparted by the $\alpha$-alkyl substituents. This conformational rigidity is a requirement to increase potency and selectivity, to improve bioavailabitlity, and to enhance the resistance to peptidases. ${ }^{1}$ In addition, the design of conformational constrained sequences is one of the approaches for development of bioactive peptides with high activity and selectivity towards a specific receptor. ${ }^{2}$ Deltorfin and Leuenkephalin analogues containing $\alpha, \alpha$-dialkyl glycine residues are examples of this strategy., ${ }^{3,4}$ Thus, $\alpha, \alpha$-dialkyl glycines are interesting building blocks for modification of peptides as probes to investigate biologically active conformations and as models for conformational analysis of the peptide backbone (formation of $\alpha$ - or $3_{10}$-helices, or $\beta$-turns). It has been observed by X-ray crystallography that a residue of $\alpha$-aminoisobutyric acid (Aib) stabilizes type II $\beta$-turn conformations in peptides having 2-4 residues; ${ }^{5}$ it is also known ${ }^{6-8}$ that when inserted in peptides Aib imparts them a $3{ }_{10}$-helical conformation, while $\alpha, \alpha$-diethyl glycine and $\alpha, \alpha$ dipropyl glycine convey fully planar $\mathrm{C}_{5}$ conformation. Bulkier substituents (diethyl, di-npropyl) favor both fully extended structures and folded helical conformations in crystal structures. ${ }^{9-11}$ However, it has been also reported that the local sequence may influence the conformation adopted at the disubstituted residue. ${ }^{12}$

It is part of our program concerning this class of amino acids to investigate the effect of incorporation of derivatives with side chains larger than methyl into biological active compounds. Now, we present the synthesis and the results of an investigation by ${ }^{1} \mathrm{H}$ NMR spectroscopy in connection with molecular mechanics calculations of the conformational behavior of four tetrapeptide analogues of the sequence B23-B26 of insulin having an $\alpha, \alpha$ dialkyl glycine residue at their $\mathrm{C}$-terminus. A considerable number of insulin analogues has 
been designed by substituting amino acid residues within its B23-B30 sequence (GlyB23-PhePhe-Tyr-Thr-Pro-Lys-ThrB30). These studies revealed that B26-des-(B27-B30)-insulin- $\mathrm{NH}_{2}$ exhibits full potency, and modification at the its N-terminus, that is, at position B26, may cause dramatic changes in its binding activity. For example, replacement of B-26-tyrosine by D-Ala raised the receptor affinity to $1250 \%$. In addition, it has been proposed that binding of insulin to its receptor needs a conformational change. ${ }^{13}$

Owing to steric hindrance related to the tetrasubstitution at their $\alpha$-carbon atom, $\alpha, \alpha$-dialkyl glycines are problematic compounds with regard both to their synthesis and to insertion into peptide chains. Nevertheless, we have been engaged in developing an improved synthesis of these amino acids ${ }^{14}$ and reports can be found in literature of incorporation of such compounds into peptides by taking advantage of various coupling reagents with different efficiencies. ${ }^{15-19}$

\section{Results and discussion}

\subsection{Synthesis}

$N$-tert-Butyloxycarbonyl-dimethyl and diethyl glycine, and $N$-benzyloxycarbonyl-dipropyl and di-isobutyl glycine were treated with DCC/HOBt followed by reaction with an aqueous solution of ammonium hydroxide ${ }^{20}$ to give the corresponding $N$-acylamino acid amides in yields of 78 , 54, 63 and 75\%, respectively. Quantitative cleavage of the N-protecting groups and coupling to $N$-Boc-phenylalanine by the DCC "pre-mix" procedure with the formation of the symmetrical anhydride in situ; ${ }^{17}$ gave the fully protected dipeptides in yields of $83,76,83$ and $50 \%$, respectively. The fully protected tetrapeptides Boc-Gly-Phe1-Phe2-X-NH dimethyl glycine (Aib), $\alpha, \alpha$-diethyl glycine (Deg), $\alpha, \alpha$-dipropyl glycine (Dpg) and $\alpha, \alpha$-diisobutyl glycine (Dbg), were then obtained by a stepwise procedure as shown in Scheme 1 in overall yields of 32, 22, 22 and 12\%, respectively, from the N-protected amino acids. These were prepared in yields varying within the range $43-68 \%$, with exception of diethyl glycine derivative, which was commercially available.

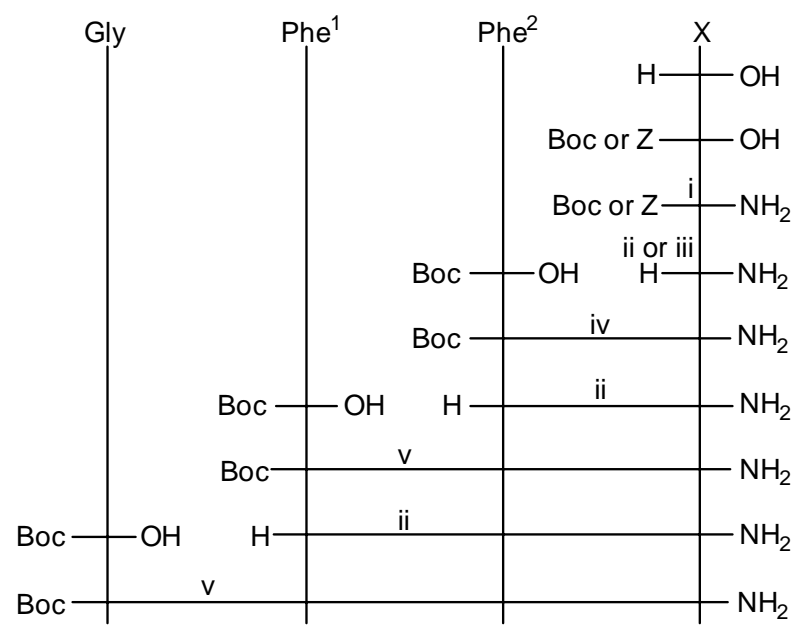

Scheme 1 i- DCC, HOBT, $\mathrm{NH}_{4} \mathrm{OH}(\operatorname{method} \mathrm{A})$; ii- TFA (method B); iii- $\mathrm{HBr} / \mathrm{HOAc}(\operatorname{method} \mathrm{C})$; ivDCC (method D); v- DCC, HOBt (method E). Boc = terc-butyloxycarbonyl; Z = benzyloxycarbonyl 


\subsection{Conformational analysis}

Diluted solutions $(5 \mathrm{mM})$ of the fully protected tetrapeptides 1-4 in DMSO- $\mathrm{d}_{6}$ were prepared for conformational ${ }^{1} \mathrm{H}$ NMR spectroscopy experiments. The room temperature spectra exhibited the number of signals that would fit either a single dominant conformation or several conformations under fast exchange. Full proton assignment was obtained by double resonance, HMQC and HMBC techniques in addition to peak splitting patterns. By means of the Karplus equation, ${ }^{21}$ $\mathrm{J} \alpha \mathrm{H}-\mathrm{NH}=6.7 \cos 2(\phi-60)-1.3 \cos (\phi-60)+1.5$, the dihedral angles $\phi$ were calculated from the NH-CH coupling constants measured in the ${ }^{1} \mathrm{H}$ spectra (Fig. 1, Table 1).

Plots of chemical shifts versus temperature were obtained for all four compounds from spectra run at various temperatures within the range 298-333 K. These were linear and allowed to calculate the variation of the amide proton chemical shifts with temperature, $\Delta \delta / \Delta \mathrm{T}$, which are shown in Table 1. Chemical exchange of the $\mathrm{NH}_{2}$ amide protons at the $\mathrm{C}$-terminal was observed on heating.

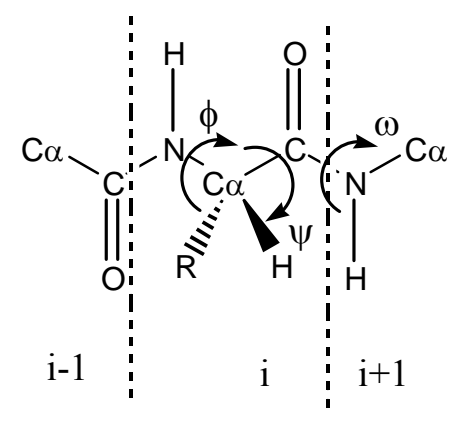

Figure 1. Definitions of the dihedral angles $\phi, \psi$ and $\omega$

Table 1. Temperature coefficients of $\mathrm{NH}$ protons, $\mathrm{J}_{\alpha \mathrm{H}-\mathrm{NH}}$ coupling and calculated dihedral angles $(\phi)$ in $\mathrm{DMSO}-\mathrm{d}_{6}$ for compounds 1-4

\begin{tabular}{|c|c|c|c|c|c|c|c|c|c|c|}
\hline \multirow[t]{3}{*}{ Compound } & \multicolumn{10}{|c|}{ Residue } \\
\hline & \multirow[t]{2}{*}{ Gly } & \multirow{2}{*}{\multicolumn{2}{|c|}{$\begin{array}{c}\text { Phe }^{1} \quad \text { Phe }^{2} \\
-\Delta \delta / \Delta \mathrm{T} \\
(\mathrm{ppb} / \mathrm{K})\end{array}$}} & \multirow[t]{2}{*}{$\mathbf{X}$} & \multicolumn{2}{|r|}{ Gly } & \multicolumn{2}{|c|}{ Phe $^{1}$} & \multicolumn{2}{|c|}{ Phe $^{2}$} \\
\hline & & & & & $\begin{array}{r}\mathbf{J}_{\alpha \mathrm{H}-\mathrm{NH}} \\
(\mathrm{Hz})\end{array}$ & $\begin{array}{c}\phi \\
\left(^{\circ}\right)\end{array}$ & $\begin{array}{c}\mathbf{J}_{\alpha \mathrm{H}-\mathrm{NH}} \\
(\mathrm{Hz})\end{array}$ & $\begin{array}{c}\phi \\
\left(^{\circ}\right)\end{array}$ & $\begin{array}{r}\mathbf{J}_{\text {aH-NH }} \\
(\mathrm{Hz})\end{array}$ & $\begin{array}{c}\phi \\
\left({ }^{\circ}\right)\end{array}$ \\
\hline 1 & 3.8 & 4.8 & 6.5 & 5.8 & 5.7 & $34 ; 87 ;-75 ;-166$ & 8.1 & $-146 ;-154$ & 6.9 & $60 ;-84 ;-156$ \\
\hline 2 & 5.0 & 6.2 & 8.2 & 2.4 & 6.0 & $83 ; 37 ;-77 ;-163$ & 8.7 & $-101 ;-139$ & 7.2 & $-86 ;-154$ \\
\hline 3 & 5.5 & 6.5 & 8.1 & 1.8 & 6.0 & $83 ; 37 ;-77 ;-163$ & 8.4 & $-97 ;-143$ & 7.5 & $-89 ;-151$ \\
\hline 4 & 6.0 & 6.7 & 8.0 & 1.8 & 6.3 & $42 ; 78 ;-79 ;-161$ & 8.7 & $-101 ;-139$ & 8.1 & $-146 ;-154$ \\
\hline
\end{tabular}

Larger $\mathrm{NH}$ temperature gradients were observed for $\mathrm{Phe}^{2}\left(\Delta \delta / \Delta \mathrm{T}=-6.5\right.$ to $\left.8.2 \mathrm{ppb} \mathrm{K}^{-1}\right)$ as compared to those for the other residues. As in DMSO- $\mathrm{d}_{6}$ solutions of peptides $\Delta \delta / \Delta \mathrm{T}$ values greater than $4 \mathrm{ppb} \mathrm{K}^{-1}$ are indicative of $\mathrm{NH}$ participation in intermolecular hydrogen bonds with solvent, ${ }^{22}$ we assume that the $\mathrm{Phe}^{2}$ amide group has an external orientation. In contrast, the low temperature coefficient, $\Delta \delta / \Delta \mathrm{T}$, observed for the $\alpha, \alpha$-dialkyl glycine $\mathrm{NH}$ proton in compounds 2-4 is in agreement with its participation in intramolecular hydrogen bonding; this effect is more pronounced in the case of compounds 3 and $\mathbf{4}\left(\Delta \delta / \Delta \mathrm{T}=-1.8 \mathrm{ppb} \mathrm{K}^{-1}\right)$, which have the largest 
side chains at their C-terminal residue. Compound 1 behaves differently; the $\mathrm{NH}$ proton of its Aib residue is sensitive to temperature (Table $1, \Delta \delta / \Delta \mathrm{T}=-5.8 \mathrm{ppb} \mathrm{K}-1$ ), and may be solvent exposed, and its glycine amide proton $\left(\Delta \delta / \Delta \mathrm{T}=-3.8 \mathrm{ppb} \mathrm{K}^{-1}\right)$, may be involved in a weak intramolecular hydrogen bond. Based on the NMR data presented above, we propose that peptides 2-4 assume a conformation stabilized by an intramolecular hydrogen bond involving the $\mathrm{NH}$ proton of the $\alpha, \alpha$-dialkyl glycine residue and the carbonyl oxygen atom of $\mathrm{Phe}^{1}$ to give rise to a seven-membered ring structure (Figure 2). This does not seem to apply to compound $\mathbf{1}$, for which our NMR data is inconclusive.

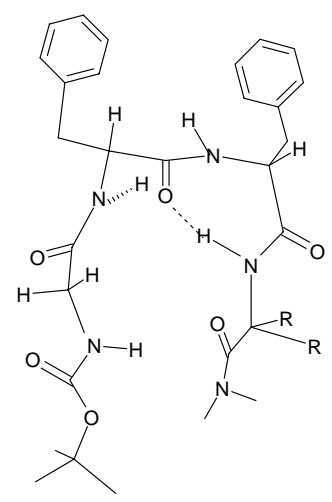

Figure 2. Representation of the conformation for compounds 2-4

A preference for a $\gamma$-turn has been reported for peptides containing an $\alpha, \alpha$-dialkylglicine, namely 1 - aminocyclopropane; ${ }^{23}$ this has been related to the polarity of solvents, ${ }^{22}$ namely DMSO as it is our case.

No information concerning the involvement of carbonyl groups in hydrogen bonds could be obtained from ${ }^{13} \mathrm{C}$ NMR data. The chemical shifts of the carbonyl group of glycine (ca. 169 ppm), Boc (ca. $156 \mathrm{ppm}$ ) and $\mathrm{Phe}^{1}$ (ca. $171.5 \mathrm{ppm}$ ) were almost invariant for all four compounds. The corresponding chemical shifts for the $\alpha, \alpha$-dialkyl glycine residues varied within the range 174.4-176.2 ppm but do not show any coherent relationship with structure. The downfield shift observed for the carbonyl carbon atom of $\mathrm{Phe}^{2}$ in compound $\mathbf{1}$ (0.8-1.1 ppm) as compared to compounds $\mathbf{2 - 4}$ suggests deshielding of this atom.

NOE difference spectra were run for the four tetrapeptides. In the case of compounds 2-4, no NOE between $\mathrm{N}_{\mathrm{i}} \mathrm{H}$ and $\mathrm{N}_{\mathrm{i}+1} \mathrm{H}$ was observed and only small NOEs between $\mathrm{C}_{\mathrm{i}} \alpha \mathrm{CH}$ and $\mathrm{N}_{\mathrm{i}+1} \mathrm{H}$ were detected. Compound 2 showed NOE values of 0.8 and $1 \%$ for $\mathrm{C} \alpha \mathrm{HPhe}^{1}-\mathrm{NHPhe}^{2}$ and $\mathrm{C} \alpha H P h e^{2}$-NHDeg, respectively. In the spectra for compounds 3 and 4, values of 0.6 and 3\% were observed for $\mathrm{C} \alpha \mathrm{HPhe}^{2}-\mathrm{NHDpg} / \mathrm{Dbg}$ and $\mathrm{CH}_{2} \mathrm{Gly}^{-\mathrm{NHPhe}}{ }^{1}$, respectively. The intra-residue NOEs $\left(\mathrm{C}_{\mathrm{i}} \alpha \mathrm{CH}-\mathrm{N}_{\mathrm{i}} \mathrm{H}\right)$ were very weak or absent in the case of compound 2. In the spectrum of compound 3, values of 5 and $0.8 \%$ were observed for $\mathrm{NH}_{-} \mathrm{CH}_{2} \mathrm{Gly}$ and $\mathrm{NHPhe}^{2}-\mathrm{C \alpha HPhe}{ }^{2}$, respectively. Compound 4 showed values of 5 and $2 \%$ for $\mathrm{NH}_{-} \mathrm{CH}_{2} \mathrm{Gly}$ and $\mathrm{NHPhe}^{1}-\mathrm{CaHPhe}{ }^{1}$, respectively. In the case of compound 1 the following NOEs were detected: NHGly-NHPhe ${ }^{1}$, 
2\%; $\mathrm{CH}_{2} \mathrm{Gly}_{-\mathrm{NHPhe}}{ }^{1}, 2 \%$; CaHPhe ${ }^{1}-\mathrm{NHPhe}^{2}$, $1 \%$; $\mathrm{C} \alpha H P h{ }^{2}-\mathrm{NHAib}, 3 \%$; NH-CH $\mathrm{CH}_{2} \mathrm{Gly}, 1 \%$; NHPhe ${ }^{1}-\mathrm{C} \alpha H P h e^{1}, 4 \%$; NHPhe ${ }^{2}-\mathrm{C} \alpha H P h e^{2}, 0.7 \%$. The NOE data confirms that our compounds do not adopt extended conformations. In fact, for extended structures small $\mathrm{N}_{\mathrm{i}} \mathrm{H}-\mathrm{N}_{\mathrm{i}+1} \mathrm{H}$ and large $\mathrm{C}_{\mathrm{i}} \alpha \mathrm{CH}-\mathrm{N}_{\mathrm{i}+1} \mathrm{H}$ NOEs are to be expected, with $\mathrm{C}_{\mathrm{i}} \alpha \mathrm{CH}-\mathrm{N}_{\mathrm{i}+1} \mathrm{H}$ NOEs larger than those for $\mathrm{C}_{\mathrm{i}} \alpha \mathrm{CH}-$ $\mathrm{N}_{\mathrm{i}} \mathrm{H}$, which does not agree with the results reported above. ${ }^{12}$

A systematic conformational search of each of the tetrapeptides was performed using the Hyperchem7.0 molecular modeling software and the AMBER force field by varying the dihedral angles of the glycine and phenylalanine residues; the set of minimum energy conformations obtained was then re-optimized with the same force field. The resulting conformations were examined and those consistent with $\mathrm{J}_{\alpha \mathrm{H}-\mathrm{NH}}$ coupling constants and hydrogen bond patterns derived from NMR data were selected as the most probable conformations in solution (Figure 3). In the case of compounds 2-4 a hydrogen bond between NH proton of the $\alpha, \alpha$-dialkyl glycine residue and the carbonyl oxygen atom of $\mathrm{Phe}^{1}$ was found, the dihedral angles calculated being close to the experimental values. The conformations calculated for these three compounds are similar and show a bend in agreement with the proposed structure that may be due to repulsive interaction of the two aromatic rings with each other. For compound 1 no intramolecular hydrogen bonding was found, but a bent conformation was also obtained. In this conformation, the values found for the diedral angles were close to the experimental ones; in addition, the NOEs observed were consistent with the calculated structure, as the distances between the interacting atoms for which NOEs were observed varied from 2.1 to $2.9 \AA$.

The tetrapeptide analogues of fragment B23-B26 of insulin having an $\alpha, \alpha$-dialkyl glycine residue at the C-terminus could be obtained by DCC promoted stepwise synthesis. The use of the DCC "pre-mix" technique proved to be efficient in the problematic coupling of Boc-Phe to the $\alpha, \alpha$-dialkyl glycine amide.

Both NMR data and molecular mechanics calculations for all compounds but one were consistent with a folded $\gamma$-turn type conformation stabilised by an intramolecular hydrogen bond; this involves the $\mathrm{NH}$ proton of the $\alpha, \alpha$-dialkyl glycine residue and the carbonyl oxygen atom of the first phenylalanine residue. The exception was the peptide having the smallest side chains at the C-terminal residue, that is, the Aib derivative (1), which exhibited a different folded conformation without intramolecular hydrogen bonding. Our results indicate that substitution of methyl at the $\alpha, \alpha$-dialkyl C-terminal residue by larger groups changes the conformational preferences of these compounds. Little conformational change was observed on branching at the $\beta$-carbon. 


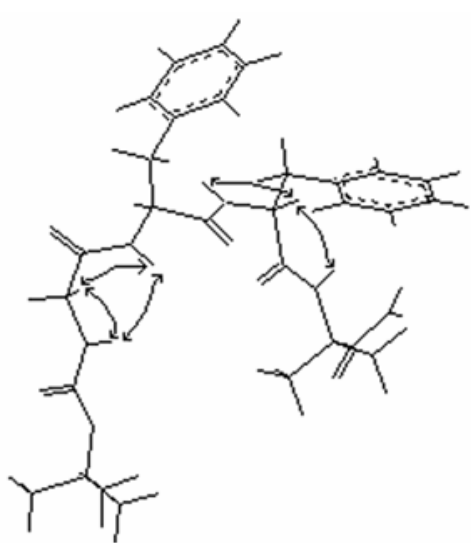

1

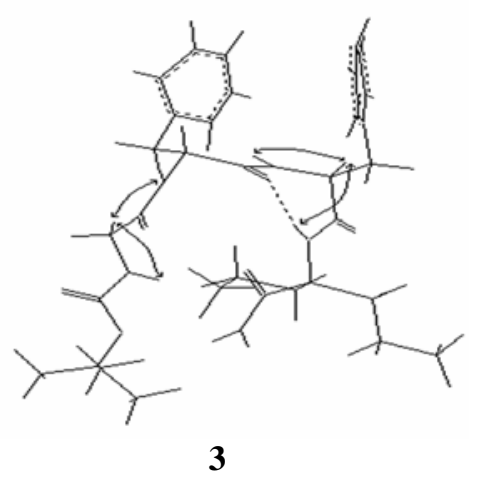

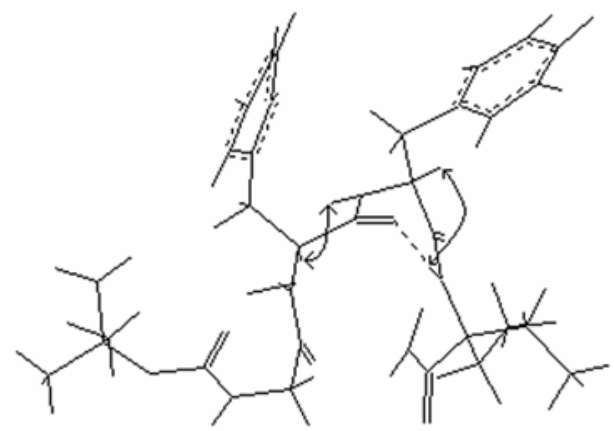

2

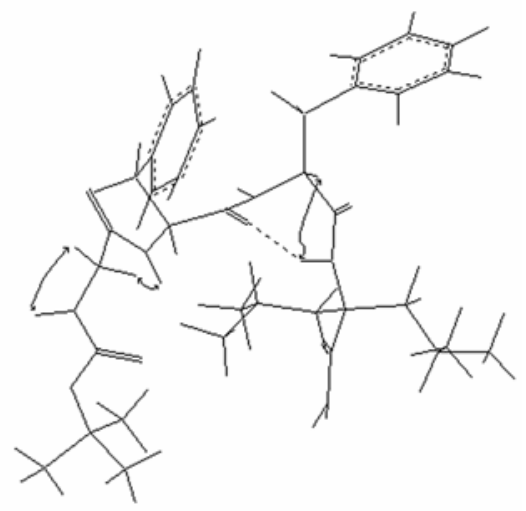

4

Figure 3. Conformations calculated for compounds 1-4. Double tipped arrows indicate the observed NOE values.

\section{Experimental}

Melting points were determined on a Gallenkamp melting point apparatus and are uncorrected. Thin layer chromatography was carried out on pre-coated plates (Merck Kieselgel $60 \mathrm{~F}_{254}$ ) and compounds were visualized by UV-light and exposure to vaporized iodine and to ninhydrin reagent. ${ }^{1} \mathrm{H}$ and ${ }^{13} \mathrm{C}$ NMR data were recorded on a Varian Unity Plus 300 Spectrometer in DMSO- $d_{6} ; \delta$ ppm were measured vs. TMS and J values are given in Hz. Double resonance, HMQC and HMBC experiments were carried out for complete assignment of proton and carbon signals in the NMR spectra. Elemental analyses were carried out on a Leco CHNS 932 instrument. Commercially available compounds, including Boc-Deg-OH, and solvents were used without previous purification; light petroleum refers to the fraction boiling at $40-60{ }^{\circ} \mathrm{C}$; the hydrobromides of $\alpha, \alpha$-dipropyl and $\alpha, \alpha$-di-isobutyl glycine were synthesized in our laboratories by a Ugi-Passerini reaction as published elsewhere ${ }^{14}$ and Boc-Phe-OH was synthesized by the standard method. ${ }^{24}$ 


\subsection{General methods}

Method A - General procedure for the synthesis of $\alpha, \alpha$-dialkyl glycine amides. The $N$-protected amino acid $(10 \mathrm{mmol})$ was dissolved in a mixture of DCM $(40 \mathrm{~mL})$ and DMF $(10 \mathrm{~mL})$; HOBt $(10.1 \mathrm{mmol})$ and DCC (10.05 mmol) were added and the mixture stirred at room temperature for $30 \mathrm{~min}$. An aqueous solution of $25 \%$ ammonium hydroxide $(13 \mathrm{mmol})$ was then added and the reaction mixture was stirred overnight. The insoluble materials were filtered off and the resulting solution was diluted with DCM $(50 \mathrm{~mL})$. The organic layer was washed successively with $5 \% \mathrm{NaHCO}_{3}$, water, $5 \%$ citric acid and water. After drying over $\mathrm{MgSO}_{4}$ and filtration, the solvent was removed under reduced pressure and the residue thus obtained crystallized from an appropriate solvent as indicated below.

Method B - General procedure for deprotection of N-tert-butyloxycarbonylamino acid amides or peptide amides. The $\mathrm{N}$-tert-butyloxycarbonyl amino acid amide or peptide amide (10 mmol) was treated with TFA $(30 \mathrm{~mL})$ at room temperature. The mixture was set aside under protection from moisture and stirred occasionally. After one to one and a half hours the excess reagent was removed under reduced pressure and the solid obtained was triturated with ether, filtered, washed with ethyl ether, dried and recrystallised from the appropriate solvent whenever indicated.

Method C - General procedure for deprotection of N-benzyloxycarbonylamino acid amides. The $\mathrm{N}$-benzyloxycarbonyl amino acid amide (10 mmol) was treated with $40 \% \mathrm{HBr}$ in acetic acid (20 $\mathrm{mL}$ ) for $1 \mathrm{~h}$ at room temperature and under occasional stirring. Ethyl ether was added to precipitate the resulting hydrobromide, which was filtered, washed with ether, dried over $\mathrm{KOH}$ in a desiccator and used without further purification.

Method D - General procedure for peptide bond formation involving $\alpha$, $\alpha$-dialkyl glycine amides. The Boc- or Z-amino acid $(10 \mathrm{mmol})$ was dissolved in dichloromethane $(30 \mathrm{~mL})$ containing DMF $(3 \mathrm{~mL})$ and treated with DCC $(5 \mathrm{mmol})$ after cooling to $0{ }^{\circ} \mathrm{C}$. The mixture was stirred for 30 minutes and the $\alpha, \alpha$-dialkyl glycine amide salt as obtained from $\mathrm{N}$-deprotection ( 5 mmol) was added followed by triethylamine $(5 \mathrm{mmol})$. After leaving the reaction mixture overnight under stirring at room temperature, the insoluble materials were filtered off, the solvent was removed under reduced pressure and the residue dissolved in ethyl acetate. The organic layer was washed successively with $5 \% \mathrm{NaHCO}_{3}$, water, $5 \%$ citric acid, water and brine. After drying over $\mathrm{MgSO}_{4}$ and filtration, the solvent was removed under reduced pressure and the resulting product crystallized from the appropriate solvent. 
Method E- General procedure for peptide bond formation. The required Boc-amino acid (10 mmol) was dissolved in dichloromethane $(40 \mathrm{~mL})$ containing DMF $(5 \mathrm{~mL})$ and treated with HOBt $(10 \mathrm{mmol})$. After cooling to $0{ }^{\circ} \mathrm{C}$, DCC $(10 \mathrm{mmol})$ was added followed by addition of the $N$-deprotected peptide amide $(10 \mathrm{mmol})$ and triethylamine $(10 \mathrm{mmol})$. After leaving the reaction mixture overnight at room temperature under stirring, it was worked up as above.

\subsection{Boc-Gly-Phe-Phe-Aib- $\mathrm{NH}_{2}$ (1)}

Boc-Aib. 2-Aminoisobutyric acid $(10 \mathrm{mmol}, 1.03 \mathrm{~g})$ was added to a mixture of water $(20 \mathrm{~mL})$, dioxan $(20 \mathrm{~mL})$ and $\mathrm{NaOH}$ solution $(10 \mathrm{mmol}, 10 \mathrm{~mL} 1 \mathrm{M})$ with vigorous stirring. The reaction mixture was cooled to $0{ }^{\circ} \mathrm{C}$ and treated with $\mathrm{Boc}_{2} \mathrm{O}(0.011 \mathrm{~mol}, 2.40 \mathrm{~g})$. Stirring was continued at room temperature for three hours and the solution concentrated under reduced pressure to remove the organic solvent. The remaining aqueous layer was then cooled to $0{ }^{\circ} \mathrm{C}$, acidified to $\mathrm{pH} 2$ with $1 \mathrm{M} \mathrm{KHSO}_{4}$ and extracted with ethyl acetate. The organic layer was washed with water and dried over $\mathrm{MgSO}_{4}$. The solvent was removed under reduced pressure and the residue thus obtained was crystallized from ethyl acetate/light petroleum. The white solid was filtered and dried to yield $61 \%$ of the required product, mp. $116-117{ }^{\circ} \mathrm{C}$ (lit. ${ }^{25}$ m.p. $117-118{ }^{\circ} \mathrm{C}$ ). ${ }^{1} \mathrm{H}$ NMR (DMSO-d $\left.d_{6}\right) \delta(\mathrm{ppm}): 1.28\left(\mathrm{~s}, 6 \mathrm{H}, 2 \times \mathrm{CH}_{3}\right), 1.35$ (s, 9H, Boc), $7.05(\mathrm{~s}, 1 \mathrm{H}, N \mathrm{H}), 12.20(\mathrm{br}$ s, $1 \mathrm{H}, \mathrm{CO}_{2} \mathrm{H}$ ). Anal. calcd for $\mathrm{C}_{9} \mathrm{H}_{17} \mathrm{NO}_{4}: \mathrm{C}: 53.20, \mathrm{H}: 8.43, \mathrm{~N}: 6.89$; found: C: $53.38, \mathrm{H}: 8.36$, N: 6.93.

Boc-Aib- $\mathrm{NH}_{2}$. General Method A was used to give the product in a yield of 78\%, mp. 168-170 ${ }^{\circ} \mathrm{C}$ (ethyl acetate/hexane). ${ }^{1} \mathrm{H}$ NMR (DMSO- $\left.d_{6}\right) \delta(\mathrm{ppm}): 1.30\left(6 \mathrm{H}, \mathrm{s}, 2 \times \mathrm{CH}_{3}\right), 1.40(9 \mathrm{H}, \mathrm{s}$, Boc), $6.70(1 \mathrm{H}, \mathrm{s}, \mathrm{NH} \mathrm{Aib}), 6.80$ and $7.00\left(2 \mathrm{H}, 2 \mathrm{~s}, \mathrm{NH}_{2}\right)$. Anal. calcd for $\mathrm{C}_{9} \mathrm{H}_{18} \mathrm{~N}_{2} \mathrm{O}_{3}: \mathrm{C}: 53.45$, H: 8.91, N: 13.85; found: C: 53.36, H: 8.62, N: 13.83 .

$\mathrm{H}$-Aib- $\mathrm{NH}_{2}$, TFA. Following Method B, one-hour after the reaction had been started ethyl ether was added and the mixture was cooled for $2 \mathrm{~h}$; the precipitated solid was filtered off, washed with ethyl ether and dried; no further purification being required. Yield 96\%, mp. 206-207 ${ }^{\circ} \mathrm{C}$. ${ }^{1} \mathrm{H}$ NMR $\left(\mathrm{DMSO}-d_{6}\right) \delta(\mathrm{ppm}): 1.40\left(\mathrm{~s}, 6 \mathrm{H}, 2 \times \mathrm{CH}_{3}\right), 7.50$ and $7.70\left(2 \mathrm{~s}, 2 \mathrm{H}, \mathrm{NH}_{2}\right), 8.10(\mathrm{br} \mathrm{s}$, $3 \mathrm{H}, \mathrm{NH}_{3}{ }^{+}$).

Boc-Phe-Aib- $\mathrm{NH}_{2}$. General Method D was used to prepare this compound as a crystalline material in a yield of $83 \%$, mp. $182-182.2{ }^{\circ} \mathrm{C}$ (from ethyl acetate/light petroleum). ${ }^{1} \mathrm{H}$ NMR $\left(\mathrm{DMSO}_{6}\right) \delta(\mathrm{ppm}): 1.24\left(\mathrm{~s}, 6 \mathrm{H}, 2 \times \mathrm{CH}_{3}\right), 1.28$ (s, 9H, Boc), 2.70-2.90 (m, 2H, $\beta \mathrm{CH}_{2}$ Phe), 4.10 (m, 1H, $\alpha \mathrm{CH}$ Phe), 6.90 (br s, 2H, NH $_{2}, 7.10$ (d, 1H, J=8.2 Hz, NH Phe), 7.30 (m, 5H, Ar), 8.00 (s, 1H, NHAib). Anal. calcd for $\mathrm{C}_{18} \mathrm{H}_{27} \mathrm{~N}_{3} \mathrm{O}_{4}$ : C: 61.87, $\mathrm{H}: 7.78, \mathrm{~N}: 12.02$; found: C: $61.75, \mathrm{H}: 8.09, \mathrm{~N}: 11.68$. 
H-Phe-Aib- $\mathrm{NH}_{2}, \mathrm{TFA}$. Following general Method B, 90 minutes after the reaction had been started a solid compound was obtained, which was used without further purification. Yield $96 \%$, mp. 269-270 ${ }^{\circ} \mathrm{C} \mathrm{dec} .{ }^{1} \mathrm{H}$ NMR (DMSO- $\left.d_{6}\right) \delta(\mathrm{ppm}): 1.24$ (s, $\left.6 \mathrm{H}, 2 \times \mathrm{CH}_{3}\right), 3.00\left(\mathrm{~m}, 2 \mathrm{H}, \beta \mathrm{CH}_{2}\right.$ Phe), 4.00 (apparent t, 1H, J=7.5 Hz, $\alpha \mathrm{CHPhe),} 6.90$ and 7.00 (2s, 2H, $\left.\mathrm{NH}_{2}\right), 7.30$ (m, 5H, Ar), 8.10 (br s, $3 \mathrm{H}, \mathrm{NH}_{3}{ }^{+}$), 8.30 (s, $1 \mathrm{H}, \mathrm{NH}$ Aib). Anal. calcd for $\mathrm{C}_{15} \mathrm{H}_{20} \mathrm{~N}_{3} \mathrm{O}_{4} \mathrm{~F}_{3}: \mathrm{C}: 49.59, \mathrm{H}: 5.55 \mathrm{H}$, $\mathrm{N}: 11.56$; found: C: 49.56, H: 5.50, N: 11.56.

Boc-Phe-Phe-Aib- $\mathrm{NH}_{2}$. General Method $\mathrm{E}$ was used to obtain the required product in a yield of 77\%, mp. 187-188 ${ }^{\circ} \mathrm{C}$ (ethyl acetate/light petroleum). ${ }^{1} \mathrm{H}$ NMR (DMSO- $d_{6}$ ) $\delta$ (ppm): 1.20 (s, $\left.6 \mathrm{H}, 2 \times \mathrm{CH}_{3}\right), 1.30$ (s, 9H, Boc), 2.85 (m, 2H, $\left.\beta \mathrm{CH}_{2} \mathrm{Phe}\right), 3.00$ (m, 2H, $\left.\beta \mathrm{CH}_{2} \mathrm{Phe}\right), 4.10(\mathrm{~m}, 1 \mathrm{H}$, $\alpha \mathrm{CH}$ Phe), 4.40 (m, 1H, $\alpha \mathrm{CH}$ Phe), 6.80-6.90 (m, 3H, NH $H_{2}$ NH Phe), 7.20 (m, 10H, Ar), 7.90 (s, $1 \mathrm{H}, \mathrm{NH}$ Aib), 8.10 (d, 1H, J=8.3 Hz, $\mathrm{NH}$ Phe). Anal. calcd for $\mathrm{C}_{27} \mathrm{H}_{36} \mathrm{~N}_{4} \mathrm{O}_{5}: \mathrm{C}: 65.30, \mathrm{H}: 7.31$ $\mathrm{H}, \mathrm{N}: 11.28$; found: C: 65.51, H: 7.33, N: 11.24.

H-Phe-Phe-Aib-NH $\mathrm{H}_{2}$ TFA. Following general Method B, 90 minutes after the reaction had been started a solid compound was obtained, which was pure by tlc and used without further purification. Yield 90\%, mp. 229-230 ${ }^{\circ} \mathrm{C} .{ }^{1} \mathrm{H}$ NMR (DMSO-d $\left.{ }_{6}\right) \delta(\mathrm{ppm}): 1.30\left(\mathrm{~s}, 6 \mathrm{H}, 2 \times \mathrm{CH}_{3}\right.$ ), 2.90 (m, 2H, $\beta \mathrm{CH}_{2}$ Phe), 3.10 (m, 2H, $\beta \mathrm{CH}_{2}$ Phe), 4.00 (m, 1H, $\alpha \mathrm{CH}$ Phe), 4.50 (m, 1H, $\alpha \mathrm{CH}$ Phe), 6.80 and $6.90\left(2 \mathrm{~s}, 2 \mathrm{H}, \mathrm{NH}_{2}\right), 7.20(\mathrm{~m}, 10 \mathrm{H}, \mathrm{Ar}), 8.00$ (br s, $\left.3 \mathrm{H}, \mathrm{NH}_{3}{ }^{+}\right), 8.10(\mathrm{~s}, 1 \mathrm{H}, \mathrm{NH}$ Aib), 8.80 (d, 1H, J=8.2 Hz, NH Phe).

Boc-Gly-Phe-Phe-Aib- $\mathrm{NH}_{2}$. General Method $\mathrm{E}$ was used to obtain the required product in a yield of $77 \%$, mp. $116-118{ }^{\circ} \mathrm{C}$ (ethyl acetate/light petroleum). ${ }^{1} \mathrm{H}$ NMR (DMSO-d ${ }_{6}$ ) $\delta$ (ppm): $1.20\left(\mathrm{~s}, 6 \mathrm{H}, 2 \times \mathrm{CH}_{3}\right), 1.30$ (s, 9H, Boc), $2.80\left(\mathrm{~m}, 2 \mathrm{H}, \beta \mathrm{CH}_{2} \mathrm{Phe}\right), 3.00$ (m, $2 \mathrm{H}, \beta \mathrm{CH}_{2}$ Phe), 3.40-3.60 (dABq, 2H, J=5.7, $16.0 \mathrm{~Hz}, \mathrm{CH}_{2} \mathrm{Gly}$, partially under water signal), $4.30(\mathrm{~m}, 1 \mathrm{H}, \alpha \mathrm{CH}$ $\mathrm{Phe}^{2}$ ), 4.50 (m, 1H, $\left.\alpha \mathrm{CH} \mathrm{Phe}^{1}\right), 6.80-6.90\left(\mathrm{~m}, 3 \mathrm{H}, \mathrm{NH}\right.$ Gly $\left.+\mathrm{NH} H_{2}\right), 7.20$ (m, 10H, Ar), 7.82 (s, 1H, NH Aib), 7.90 (d, 1H, J=8.1 Hz, NH Phe $\left.{ }^{1}\right), 8.37$ (d, 1H, J=6.9 Hz, NHPhe ${ }^{2}$ ). ${ }^{13} \mathrm{C}$ NMR $\left(\right.$ DMSO-d $\left._{6}\right) \delta$ (ppm): 176.2 (CO Aib), 171.3 (CO Phe ${ }^{1}$ ), 170.0 (CO Phe ${ }^{2}$ ), 169.2 (CO Gly), 155.7 (CO Boc), $137.6(2 \times C \mathrm{Ar}), 136.43(2 \times \mathrm{CH} \mathrm{Ar}), 129.2(2 \times \mathrm{CH} \mathrm{Ar}), 128.1(2 \times \mathrm{CH} \mathrm{Ar})$, $128.0(2 \times \mathrm{CH} \mathrm{Ar}), 126.3(2 \times \mathrm{CH} \mathrm{Ar}), 78.0$ (C Boc), 55.8 (C Aib), $54.6\left(\alpha C H \mathrm{Phe}^{2}\right), 53.6$ $\left(\alpha C H\right.$ Phe $\left.{ }^{1}\right), 43.0\left(\mathrm{CH}_{2}\right.$ Gly), 37.5 ( $\beta \mathrm{CH}_{2}$ Phe), $36.9\left(\beta C \mathrm{H}_{2} \mathrm{Phe}\right), 28.2\left(3 \times \mathrm{CH}_{3} \mathrm{Boc}\right), 25.3\left(\mathrm{CH}_{3}\right.$ Aib), $24.3\left(\mathrm{CH}_{3} \mathrm{Aib}\right)$. Anal. calcd for $\mathrm{C}_{29} \mathrm{H}_{39} \mathrm{~N}_{5} \mathrm{O}_{6}: \mathrm{C}: 62.91, \mathrm{H}: 7.10, \mathrm{~N}: 12.65$; found: $\mathrm{C}$ 63.03, $7.09 \mathrm{H}, 12.61$. 


\subsection{Boc-Gly-Phe-Phe-Deg-NH2 (2)}

Boc-Deg- $\mathrm{NH}_{2}$. General Method A was used to obtain the required product in a yield of $54 \%$, mp. $155-156{ }^{\circ} \mathrm{C}$ (ethyl acetate/light petroleum). ${ }^{1} \mathrm{H}$ NMR (DMSO-d $\left.\mathrm{d}_{6}\right) \delta$ (ppm): 0.64 (t, 6H, $\mathrm{J}=7.2 \mathrm{~Hz}, 2 \times \mathrm{CH}_{3}$ ), 1.36 (s, 9H, Boc), 1.64-2.07 (m, 4H, $2 \times \mathrm{CH}_{2}$ ), 6.09 (s, 1H, NH Deg), 7.29 and $7.45\left(2 \mathrm{~s}, 2 \mathrm{H}, \mathrm{NH}_{2}\right)$. Anal. calcd for $\mathrm{C}_{11} \mathrm{H}_{22} \mathrm{~N}_{2} \mathrm{O}_{3}: \mathrm{C}: 57.37, \mathrm{H}: 9.63, \mathrm{~N}: 12.16$; found: $\mathrm{C}$ : 57.51, H: 9.60, N: 12.11 .

H-Deg-NH $\mathrm{N}_{2}$ TFA. Following general Method B, 90 minutes after the reaction had been started a solid compound was obtained in a quantitative yield, which was pure by tlc and used without further purification. ${ }^{1} \mathrm{H}$ NMR (DMSO- $\left.d_{6}\right) \delta(\mathrm{ppm}): 0.86\left(\mathrm{t}, 6 \mathrm{H}, \mathrm{J}=7.1 \mathrm{~Hz}, \mathrm{CH}_{3}\right), 1.60-1.90$ (m, $\left.4 \mathrm{H}, 2 \times \mathrm{CH}_{2}\right), 7.62$ and $7.73\left(2 \mathrm{~s}, 2 \mathrm{H}, \mathrm{NH}_{2}\right), 7.95\left(\mathrm{~s}, 3 \mathrm{H}, \mathrm{NH}_{3}{ }^{+}\right)$.

Boc-Phe-Deg- $\mathrm{NH}_{2}$. General Method D was used to obtain the required product in a yield of $76 \%$, mp. $218-219{ }^{\circ} \mathrm{C}$ (ethyl acetate/light petroleum). ${ }^{1} \mathrm{H}$ NMR (DMSO- $d_{6}$ ) $\delta$ (ppm): 0.56 (t, 3H, $\left.\mathrm{J}=7.3 \mathrm{~Hz}, \mathrm{CH}_{3}\right), 0.64$ (t, 3H, J=7.3 Hz, $\left.\mathrm{CH}_{3}\right), 1.29$ (s, 9H, Boc), $1.63\left(\mathrm{~m}, 2 \mathrm{H}, \mathrm{CH}_{2}\right), 2.34(\mathrm{~m}, 2 \mathrm{H}$, $\mathrm{CH}_{2}$ ), 2.74-3.00 (m, 2H, $\beta \mathrm{CH}_{2}$ Phe), $3.90(\mathrm{~m}, 1 \mathrm{H}, \alpha \mathrm{CH}$ Phe), 7.26 (m, 5H, Ar), 7.37 and 7.48 $\left(2 \mathrm{~s}, 2 \mathrm{H}, \mathrm{NH}_{2}\right), 7.49(\mathrm{~d}, 1 \mathrm{H}, \mathrm{J}=7.8 \mathrm{~Hz}, \mathrm{NH}$ Phe), 7.68 (s, 1H, NH Deg). Anal. calcd for $\mathrm{C}_{20} \mathrm{H}_{31} \mathrm{~N}_{3} \mathrm{O}_{4}: \mathrm{C}: 63.63, \mathrm{H}: 8.28, \mathrm{~N}: 11.13$; found: C: $63.54, \mathrm{H}: 8.40, \mathrm{~N}: 11.05$.

H-Phe-Deg- $\mathrm{NH}_{2}$,TFA. Following general Method B, 90 minutes after the reaction had been started a solid compound was obtained in a yield of $98 \%$, which required no further purification, mp. 230-231 ${ }^{\circ} \mathrm{C}$ dec. ${ }^{1} \mathrm{H}$ NMR (DMSO-d $\left.{ }_{6}\right) \delta(\mathrm{ppm}): 0.47$ (t, 3H, J=7.3 Hz, $\mathrm{CH}_{3}$ ), 0.61 (t, 3H, $\left.\mathrm{J}=7.3 \mathrm{~Hz}, \mathrm{CH}_{3}\right), 1.63\left(\mathrm{~m}, 2 \mathrm{H}, \mathrm{CH}_{2}\right), 2.20\left(\mathrm{~m}, 2 \mathrm{H}, \mathrm{CH}_{2}\right), 2.80\left(\mathrm{dd}, 1 \mathrm{H}, \mathrm{J}=7.3,13.8 \mathrm{~Hz}, \beta_{\mathrm{CH}}\right.$ Phe), 3.10 (dd, $1 \mathrm{H}, \mathrm{J}=7.3$ and $13.9 \mathrm{~Hz}, \beta \mathrm{CH}_{2} \mathrm{Phe}$ ), 4.36 (m, $1 \mathrm{H}, \alpha \mathrm{CH}$ Phe), 7.36 (s, $1 \mathrm{H}, \mathrm{NH}_{2}$ ), $7.32\left(\mathrm{~m}, 6 \mathrm{H}, \mathrm{Ar}+\mathrm{NH}_{2}\right), 7.89(\mathrm{~s}, 1 \mathrm{H}, \mathrm{NH} \mathrm{Deg}), 8.15$ (br s, 3H, $\left.\mathrm{NH}_{3}{ }^{+}\right)$. Anal. calcd for $\mathrm{C}_{17} \mathrm{H}_{24} \mathrm{~N}_{3} \mathrm{O}_{4} \mathrm{~F}_{3}$ : C: 52.17, H: 6.14, N: 10.74; found: C: 51.58, H: 6.11, N: 10.62 .

Boc-Phe-Phe-Deg- $\mathrm{NH}_{2}$. General Method $\mathrm{E}$ was used to obtain the required product in a yield of $83 \%$, mp. $113-115{ }^{\circ} \mathrm{C}$ (ethyl acetate/light petroleum). ${ }^{1} \mathrm{H}$ NMR (DMSO- $\left.d_{6}\right) \delta(\mathrm{ppm}): 0.51$ (t, 3H, $\left.\mathrm{J}=7.3 \mathrm{~Hz}, \mathrm{CH}_{3}\right), 0.63$ (t, 3H, J=7.3 Hz, $\left.\mathrm{CH}_{3}\right), 1.25$ (s, 9H, Boc), 1.65 (m, 2H, $\left.\mathrm{CH}_{2}\right), 2.27$ (m, 2H, $\mathrm{CH}_{2}$ ), 2.86 (m, 2H, $\beta \mathrm{CH}_{2}$ Phe), 3.07 (m, 2H, $\left.\beta \mathrm{CH}_{2} \mathrm{Phe}\right), 4.17$ (m, $1 \mathrm{H}, \alpha \mathrm{CH}$ Phe), 4.40 (m, $1 \mathrm{H}$, $\alpha \mathrm{CH}$ Phe), 6.87 (d, 1H, J=8.5 Hz, NH Phe), 7.30 and $7.40\left(2 \mathrm{~s}, 2 \mathrm{H}, \mathrm{NH}_{2}\right), 7.27$ (m, 10H, Ar), 7.60 (s, $1 \mathrm{H}, \mathrm{NH}$ Deg), 8.60 (d, $1 \mathrm{H}, \mathrm{J}=7.6 \mathrm{~Hz}, \mathrm{NH}$ Phe). Anal. calcd for $\mathrm{C}_{29} \mathrm{H}_{40} \mathrm{~N}_{4} \mathrm{O}_{5}: \mathrm{C}: 66.39$, H: 7.68, N: 10.68; found: C: 66.00, H: 7.92, N: 10.37 . 
H-Phe-Phe-Deg- $\mathrm{NH}_{2}, \mathrm{TFA}$. Following general Method B, 90 minutes after the reaction had been started a solid compound was obtained, which was pure by tlc and used without further purification. Yield 86\%, mp. 127-130 ${ }^{\circ} \mathrm{C} .{ }^{1} \mathrm{H}$ NMR (DMSO- $\left.d_{6}\right) \delta(\mathrm{ppm}): 0.54$ (t, 3H, J=7.3 Hz, $\left.\mathrm{CH}_{3}\right), 0.65\left(\mathrm{t}, 3 \mathrm{H}, \mathrm{J}=7.3 \mathrm{~Hz}, \mathrm{CH}_{3}\right), 1.68\left(\mathrm{~m}, 2 \mathrm{H}, \mathrm{CH}_{2}\right), 2.30\left(\mathrm{~m}, 2 \mathrm{H}, \mathrm{CH}_{2}\right), 2.80\left(\mathrm{~m}, 2 \mathrm{H}, \beta_{\mathrm{CH}}\right.$ Phe), 3.10 (m, 2H, $\beta \mathrm{CH}_{2}$ Phe), 3.95 (m, 1H, $\alpha \mathrm{CH}$ Phe), 4.50 (m, 1H, $\alpha \mathrm{CH}$ Phe), 7.30 (m, 10H, Ar), 7.40 and $7.50\left(2 \mathrm{~s}, 2 \mathrm{H}, \mathrm{NH}_{2}\right), 7.63\left(\mathrm{~s}, 1 \mathrm{H}, \mathrm{NH}\right.$ Deg), 8.10 (br s, 3H, $\left.\mathrm{NH}_{3}{ }^{+}\right), 9.13(\mathrm{~d}, 1 \mathrm{H}$, $\mathrm{J}=7.6 \mathrm{~Hz}, \mathrm{NH}$ Phe).

Boc-Gly-Phe-Phe-Deg- $\mathrm{NH}_{2}$. General Method E was used to obtain the required product in a yield of $75 \%$, mp. $218-219{ }^{\circ} \mathrm{C}$ (ethyl acetate/light petroleum). ${ }^{1} \mathrm{H}$ NMR (DMSO- $\left.d_{6}\right) \delta(\mathrm{ppm})$ : 0.55 (t, 3H, J=7.3 Hz, CH $\mathrm{CH}_{3}, 0.64$ (t, 3H, J=7.3 Hz, CH $\mathrm{CH}_{3}, 1.30$ (s, 9H, Boc), 1.70 (m, 2H, $\mathrm{CH}_{2}$ ), 2.30 (m, $2 \mathrm{H}, \mathrm{CH}_{2}$ ), 2.60-2.80 (m, $2 \mathrm{H}, \beta \mathrm{CH}_{2} \mathrm{Phe}$ ), 3.10 (m, $2 \mathrm{H}, \beta \mathrm{CH}_{2} \mathrm{Phe}$ ), 3.30-3.60 (dABq, $2 \mathrm{H}, \mathrm{J}=5.7,16.8 \mathrm{~Hz}, \mathrm{CH}_{2}$ Gly, partially under the water signal), $4.35\left(\mathrm{~m}, 1 \mathrm{H}, \alpha \mathrm{CH} \mathrm{Phe}^{2}\right), 4.54$ (m, 1H, $\left.\alpha \mathrm{CH} \mathrm{Phe}^{1}\right), 6.78(\mathrm{t}, 1 \mathrm{H}, \mathrm{J}=6.0 \mathrm{~Hz}, \mathrm{NH}$ Gly), $7.22(\mathrm{~m}, 10 \mathrm{H}, \mathrm{Ar}), 7.37$ and $7.44(2 \mathrm{~s}, 2 \mathrm{H}$, $\mathrm{NH}_{2}$ ), 7.57 (s, 1H, NH Deg), 7.92 (d, 1H, J=8.7 Hz, NH Phe ${ }^{1}$ ), 8.75 (d, 1H, J=7.2 Hz, NH $\mathrm{Phe}^{2}$ ). ${ }^{13} \mathrm{C}$ NMR (DMSO-d 6 ) $\delta$ (ppm): 174.4 (CO Deg), 171.6 (CO Phe $\left.{ }^{1}\right), 169.2\left(C O \mathrm{Phe}^{2}\right)$, 168.8 (CO Gly), 155.6 (CO Boc), 138.0 (C Ar), 137.9 (C Ar), 129.2 (2 $\times$ CH Ar), $129.0(2 \times$ CH Ar), $128.2(2 \times \mathrm{CH} \mathrm{Ar}), 127.9$ ( $2 \times \mathrm{CH} \mathrm{Ar}), 126.3(\mathrm{CH} \mathrm{Ar}), 126.2(\mathrm{CH} \mathrm{Ar}), 78.0(C \mathrm{Boc})$, 64.0 (C Deg), $55.5\left(\alpha C H P^{2}\right)^{2}, 53.5\left(\alpha C H\right.$ Phe $\left.{ }^{1}\right), 42.9\left(\mathrm{CH}_{2}\right.$ Gly), 37.9 ( $\left.\beta C \mathrm{H} 2 \mathrm{Phe}\right), 37.0$ ( $\beta C \mathrm{CH} 2 \mathrm{Phe}), 28.2\left(3 \times \mathrm{CH}_{3} \mathrm{Boc}\right), 27.2\left(\mathrm{CH}_{2} \mathrm{Deg}\right), 24.5\left(\mathrm{CH}_{2} \mathrm{Deg}\right), 8.1\left(\mathrm{CH}_{3} \mathrm{Deg}\right), 7.8\left(\mathrm{CH}_{3}\right.$ Deg). Anal. calcd for $\mathrm{C}_{31} \mathrm{H}_{43} \mathrm{~N}_{5} \mathrm{O}_{6}: \mathrm{C}: 64.00, \mathrm{H}: 7.45, \mathrm{~N}: 12.04$; found: $\mathrm{C}: 63.84, \mathrm{H}: 7.56, \mathrm{~N}$ : 11.86

\subsection{Boc-Gly-Phe-Phe-Dpg- $\mathrm{NH}_{2}$ (3)}

Z-Dpg-OH. The amino acid hydrobromide (10,8 mmol, $2.12 \mathrm{~g})$ was dissolved in $1 \mathrm{M} \mathrm{NaOH}$ $(21.6 \mathrm{ml})$ and stirred with cooling in an ice bath. A solution of benzyl chloroformate was added dropwise with the $\mathrm{pH}$ kept at 11 by addition of $1 \mathrm{M} \mathrm{NaOH}$ under vigorous stirring; the temperature was then raised to $40{ }^{\circ} \mathrm{C}$ and maintained as such for 4 hours, while the $\mathrm{pH}$ was kept at 11 . The mixture was then extracted with four portions of ethyl ether, the aqueous layer cooled and the $\mathrm{pH}$ adjusted to 1.5 by addition of $6 \mathrm{M} \mathrm{HCl}$. The oil thus formed was extracted into ethyl acetate and the solution dried over $\mathrm{MgSO}_{4}$. The solvent was removed under reduced pressure to give an oil that crystallized on standing. Yield $68 \%$, mp. $76-78{ }^{\circ} \mathrm{C} .{ }^{1} \mathrm{H}$ NMR (DMSO- $\left.d_{6}\right) \delta$ (ppm): $0.80\left(\mathrm{t}, 6 \mathrm{H}, \mathrm{J}=7.1 \mathrm{~Hz}, 2 \times \mathrm{CH}_{3}\right), 1.10\left(\mathrm{~m}, 4 \mathrm{H}, 2 \times \mathrm{CH}_{2}\right), 1.65\left(\mathrm{~m}, 4 \mathrm{H}, 2 \times \mathrm{CH}_{2}\right), 5.00(\mathrm{~s}$, $2 \mathrm{H}, \mathrm{CH}_{2} \mathrm{Ar}$ ), 7.00 (s, $\left.1 \mathrm{H}, \mathrm{NH} \mathrm{Dpg}\right), 7.30(\mathrm{~m}, 5 \mathrm{H}, \mathrm{Ar}), 12.60$ (br s, $1 \mathrm{H}, \mathrm{CO}_{2} H$ ). Anal. calcd for $\mathrm{C}_{16} \mathrm{H}_{23} \mathrm{NO}_{4}: \mathrm{C}: 65.51, \mathrm{H}: 7.90, \mathrm{~N}: 4.78$; found: $\mathrm{C}: 65.24, \mathrm{H}: 7.79, \mathrm{~N}: 5.08$. 
$\mathrm{Z}-\mathrm{Dpg}-\mathrm{NH}_{2}$. General Method A was used to give the product in a yield of $62 \%$, mp. $155-156^{\circ} \mathrm{C}$ (ethyl ether/light petroleum). ${ }^{1} \mathrm{H}$ NMR (DMSO- $\left.d_{6}\right) \delta(\mathrm{ppm}): 0.80\left(\mathrm{t}, 6 \mathrm{H}, \mathrm{J}=7.2 \mathrm{~Hz}, 2 \times \mathrm{CH}_{3}\right.$ ), $1.10\left(\mathrm{~m}, 4 \mathrm{H}, 2 \times \mathrm{CH}_{2}\right), 1.60\left(\mathrm{~m}, 2 \mathrm{H}, \mathrm{CH}_{2}\right), 2.00\left(\mathrm{~m}, 2 \mathrm{H}, \mathrm{CH}_{2}\right), 5.00\left(\mathrm{~s}, 2 \mathrm{H}, \mathrm{CH}_{2} \mathrm{Ar}\right), 6.50(\mathrm{~s}, 1 \mathrm{H}$, $\mathrm{NH}$ Dpg), $7.30\left(\mathrm{~m}, 6 \mathrm{H}, \mathrm{Ar}+\mathrm{NH}_{2}\right), 7.45\left(\mathrm{~s}, 1 \mathrm{H}, \mathrm{NH}_{2}\right)$. Anal. calcd for $\mathrm{C}_{16} \mathrm{H}_{24} \mathrm{~N}_{2} \mathrm{O}_{3}: \mathrm{C}: 65.73, \mathrm{H}$ : 8.27, N: 9.58; found: C: 66.02, H: 8.49, N: 9.63.

$\mathrm{H}$-Dpg- $\mathrm{NH}_{2}, \mathrm{HBr}$. Following general Method C, a solid compound was obtained, which was pure by tlc and used without further purification. Yield 93\%, mp. 227-229 ${ }^{\circ} \mathrm{C} .{ }^{1} \mathrm{H}$ NMR $\left(\mathrm{DMSO}_{6}\right) \delta(\mathrm{ppm}): 0.80\left(\mathrm{t}, 6 \mathrm{H}, \mathrm{J}=6.9 \mathrm{~Hz}, 2 \times \mathrm{CH}_{3}\right), 1.10\left(\mathrm{~m}, 2 \mathrm{H}, \mathrm{CH}_{2}\right), 1.40\left(\mathrm{~m}, 2 \mathrm{H}, \mathrm{CH}_{2}\right)$, $1.70\left(\mathrm{~m}, 4 \mathrm{H}, \mathrm{CH}_{2}\right), 7.60$ and $7.70\left(2 \mathrm{~s}, 2 \mathrm{H}, \mathrm{NH}_{2}\right), 7.90\left(\mathrm{~s}, 3 \mathrm{H}, \mathrm{NH}_{3}{ }^{+}\right)$.

Boc-Phe-Dpg- $\mathrm{NH}_{2}$. General Method D was used to obtain the required product in a yield of 83\%, mp. 191-192 ${ }^{\circ} \mathrm{C}$ (ethyl acetate/light petroleum). ${ }^{1} \mathrm{H}$ NMR (DMSO- $d_{6}$ ) $\delta$ (ppm): 0.80-0.90 $\left(\mathrm{m}, 8 \mathrm{H}, 2 \times \mathrm{CH}_{3}+\mathrm{CH}_{2}\right), 1.30\left(\mathrm{~s}+\mathrm{m}, 11 \mathrm{H}, \mathrm{Boc}+\mathrm{CH}_{2}\right), 1.55\left(\mathrm{~m}, 2 \mathrm{H}, \mathrm{CH}_{2}\right), 2.30\left(\mathrm{~m}, 2 \mathrm{H}, \mathrm{CH}_{2}\right)$, 2.70-2.90 (dd, $1 \mathrm{H}, \mathrm{J}=10.8,13.2, \beta \mathrm{CH}_{2}$ Phe), 3.00 (dd, $1 \mathrm{H}, \mathrm{J}=4.8,13.7 \mathrm{~Hz}, \beta \mathrm{CH}_{2} \mathrm{Phe}$ ), 3.90 (m, 1H, $\alpha \mathrm{CH}$ Phe), $7.25(\mathrm{~m}, 5 \mathrm{H}, \mathrm{Ar}), 7.50\left(\mathrm{~d}+\mathrm{s}, 2 \mathrm{H}, \mathrm{NH} \mathrm{Phe}+\mathrm{NH}_{2}\right), 7.40\left(\mathrm{~s}, 1 \mathrm{H}, \mathrm{NH}_{2}\right), 7.65(\mathrm{~s}$, $1 \mathrm{H}, \mathrm{NH}$ Dpg). Anal. calcd for $\mathrm{C}_{22} \mathrm{H}_{35} \mathrm{~N}_{3} \mathrm{O}_{4}: \mathrm{C}: 65.16, \mathrm{H}: 8.70, \mathrm{~N}: 10.36$; found: C: $65.15, \mathrm{H}$ : $8.75, \mathrm{~N}: 10.24$.

H-Phe-Dpg- $\mathrm{NH}_{2}$,TFA. Following general Method B, a solid compound was obtained, which was pure by tlc and used without further purification. Yield $88 \%$, mp. $232-233{ }^{\circ} \mathrm{C} \mathrm{dec} .{ }^{1} \mathrm{H}$ NMR $\left(\mathrm{DMSO}_{6}\right) \delta$ (ppm): 0.60-0.90 (m, 8H, $\left.2 \times \mathrm{CH}_{3}+\mathrm{CH}_{2}\right), 1.20\left(\mathrm{~m}, 2 \mathrm{H}, \mathrm{CH}_{2}\right), 1.60\left(\mathrm{~m}, 2 \mathrm{H}, \mathrm{CH}_{2}\right)$, 2.00-2.20 (m, 2H, $\mathrm{CH}_{2}$ ), 2.90 (dd, $1 \mathrm{H}, \mathrm{J}=7.3,13.8 \mathrm{~Hz}, \beta \mathrm{CH}_{2}$ Phe), 3.00 (dd, $1 \mathrm{H}, \mathrm{J}=7.3,13.9 \mathrm{~Hz}$, $\beta \mathrm{CH}_{2}$ Phe), 4.30 (t, $1 \mathrm{H}, \mathrm{J}=7.3 \mathrm{~Hz}, \alpha \mathrm{CH}$ Phe), 7.20-7.45 (m, 7H, $\left.\mathrm{Ar}+\mathrm{NH}_{2}\right), 7.85(\mathrm{~s}, 1 \mathrm{H}, \mathrm{NH}$ Dpg), 8.15 (br s, $3 \mathrm{H}, \mathrm{NH}_{3}{ }^{+}$). Anal. calcd for $\mathrm{C}_{19} \mathrm{H}_{28} \mathrm{~N}_{3} \mathrm{O}_{4} \mathrm{~F}_{3}$ : C: 54.41, H: 6.68, N: 10.02; found: C: 54.06, H: 6.42, N: 9.97.

Boc-Phe-Phe-Dpg- $\mathrm{NH}_{2}$. General Method E was used to obtain the required product in a yield of 69\%, mp. 106-108 ${ }^{\circ} \mathrm{C}$ (ethyl acetate/light petroleum). ${ }^{1} \mathrm{H}$ NMR (DMSO- $d_{6}$ ) $\delta$ (ppm): 0.75 (m, $\left.6 \mathrm{H}, 2 \times \mathrm{CH}_{3}\right), 0.90\left(\mathrm{~m}, 2 \mathrm{H}, \mathrm{CH}_{2}\right), 1.10\left(\mathrm{~m}, 2 \mathrm{H}, \mathrm{CH}_{2}\right), 1.30(\mathrm{~s}, 9 \mathrm{H}, \mathrm{Boc}), 1.60\left(\mathrm{~m}, 2 \mathrm{H}, \mathrm{CH}_{2}\right), 2.20$ (m, 2H, $\mathrm{CH}_{2}$ ), 2.55- 2.90 (m, 2H, $\beta \mathrm{CH}_{2} \mathrm{Phe}$ ), 2.90-3.10 (m, $\left.2 \mathrm{H}, \beta \mathrm{CH}_{2} \mathrm{Phe}\right), 4.20$ (m, $1 \mathrm{H}, \alpha \mathrm{CH}$ Phe), 4.40 (m, 1H, $\alpha \mathrm{CH}$ Phe), 6.85 (d, 1H, J=8.2 Hz, NH Phe), $7.20\left(\mathrm{~m}, 11 \mathrm{H}, \mathrm{Ar}+\mathrm{NH}_{2}\right), 7.40$ $\left(\mathrm{s}, 1 \mathrm{H}, \mathrm{NH}_{2}\right), 7.55(\mathrm{~s}, 1 \mathrm{H}, \mathrm{NH} \mathrm{Dpg}), 8.50(\mathrm{~d}, 1 \mathrm{H}, \mathrm{J}=7.5 \mathrm{~Hz}, \mathrm{NH}$ Phe). Anal. calcd for $\mathrm{C}_{31} \mathrm{H}_{44} \mathrm{~N}_{4} \mathrm{O}_{5}$ : C: 67.34, H: 8.02, N: 10.14; found: C 67.08, H: 8.21, N: 9.86. 
H-Phe-Phe-Dpg-NH, TFA. Following general Method B, 90 minutes after the reaction had been started a solid compound was obtained, which was pure by tlc and used without further purification. Yield 89\%, mp. 126-128 ${ }^{\circ} \mathrm{C} .{ }^{1} \mathrm{H}$ NMR (DMSO- $\left.d_{6}\right) \delta(\mathrm{ppm}): 0.75\left(\mathrm{~m}, \mathrm{H}, 2 \times \mathrm{CH}_{3}\right.$ ), 0.80-1.00 (m, 2H, $\left.\mathrm{CH}_{2}\right), 1.00-1.10\left(\mathrm{~m}, 2 \mathrm{H}, \mathrm{CH}_{2}\right), 1.60\left(\mathrm{~m}, 2 \mathrm{H}, \mathrm{CH}_{2}\right), 2.20\left(\mathrm{~m}, 2 \mathrm{H}, \mathrm{CH}_{2}\right), 2.70-$ $2.90\left(\mathrm{~m}, 2 \mathrm{H}, \quad \beta \mathrm{CH}_{2} \mathrm{Phe}\right.$ ), 3.10 (dd, $\left.2 \mathrm{H}, \mathrm{J}=5.6,13.9 \mathrm{~Hz}, \beta \mathrm{CH}_{2} \mathrm{Phe}\right), 3.95$ (m, $1 \mathrm{H}, \alpha \mathrm{CH}$ Phe), $4.50(\mathrm{~m}, 1 \mathrm{H}, \alpha \mathrm{CH} \mathrm{Phe}), 7.20-7.40\left(\mathrm{~m}, 11 \mathrm{H}, \mathrm{Ar}+\mathrm{NH}_{2}\right), 7.45\left(1 \mathrm{~s}, 1 \mathrm{H}, \mathrm{NH}_{2}\right), 7.60(\mathrm{~s}, 1 \mathrm{H}, \mathrm{NH}$ Dpg), 8.00 (br s, $\left.3 \mathrm{H}, \mathrm{NH}_{3}^{+}\right), 9.10(\mathrm{~d}, 1 \mathrm{H}, \mathrm{J}=7.9 \mathrm{~Hz}, \mathrm{NH}$ Phe).

Boc-Gly-Phe-Phe-Dpg- $\mathrm{NH}_{2}$. General Method E was used to obtain the required product in a yield of $86 \%$, mp. $120-122{ }^{\circ} \mathrm{C}$ (ethyl acetate/light petroleum). ${ }^{1} \mathrm{H}$ NMR (DMSO- $\left.d_{6}\right) \delta$ (ppm): $0.75\left(\mathrm{~m}, 6 \mathrm{H}, 2 \times \mathrm{CH}_{3}\right), 0.80-1.00\left(\mathrm{~m}, 2 \mathrm{H}, \mathrm{CH}_{2}\right), 1.00-1.10\left(\mathrm{~m}, 2 \mathrm{H}, \mathrm{CH}_{2}\right), 1.30(\mathrm{~s}, 9 \mathrm{H}, \mathrm{Boc}), 1.60$ (m, 2H, $\mathrm{CH}_{2}$ ), $2.20\left(\mathrm{~m}, 2 \mathrm{H}, \mathrm{CH}_{2}\right), 2.60-2.90\left(\mathrm{~m}, 2 \mathrm{H}, \mathrm{\beta CH}_{2} \mathrm{Phe}\right), 3.10$ (dd, 2H, J=5.7, $13.9 \mathrm{~Hz}$, $\mathrm{\beta CH}_{2}$ Phe), 3.30-3.50 (dABq, $2 \mathrm{H}, \mathrm{J}=6.0,16.2 \mathrm{~Hz}, \mathrm{CH}_{2} \mathrm{Gly}$, partially under water signal), 4.30 (m, 1H, $\left.\alpha \mathrm{CH} \mathrm{Phe}^{2}\right), 4.50$ (m, 1H, $\alpha \mathrm{CH} \mathrm{Phe}^{1}$ ), 6.80 (t, 1H, J=6.0 Hz, NH Gly), 7.00-7.20 (m, $10 \mathrm{H}, \mathrm{Ar}), 7.30$ and $7.40\left(2 \mathrm{~s}, 2 \mathrm{H}, \mathrm{NH}_{2}\right), 7.50$ (s, 1H, NH Dpg), 7.90 (d, 1H, J=8.6 Hz, NH Phe ${ }^{1}$ ), $8.70\left(\mathrm{~d}, 1 \mathrm{H}, \mathrm{J}=7.6 \mathrm{~Hz}, \mathrm{NH} \mathrm{Phe}^{2}\right.$ ). ${ }^{13} \mathrm{C}$ NMR (DMSO-d $\left.{ }_{6}\right) \delta$ (ppm): 174.7 (CO Dpg), 171.5 (CO $\mathrm{Phe}^{1}$ ), 168.9 (CO Phe $), 168.8$ (CO Gly), 155.6 (CO Boc), 137.9 ( $2 \times$ C Ar), 129.2 (2 $\times$ CH Ar), $129.0(2 \times \mathrm{CH} \mathrm{Ar}), 128.2(2 \times \mathrm{CH} \mathrm{Ar}), 127.9(2 \times \mathrm{CH} \mathrm{Ar}), 126.3(\mathrm{CH} \mathrm{Ar}), 126.2(\mathrm{CH} \mathrm{Ar}), 78.0$

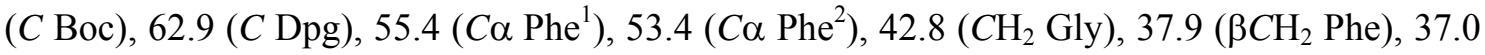
( $\left.\beta \mathrm{CH}_{2} \mathrm{Phe}\right), 36.9\left(\mathrm{CH}_{2}\right), 36.8\left(\mathrm{CH}_{2}\right), 28.2\left(3 \times \mathrm{CH}_{3} \mathrm{Boc}+\mathrm{CH}_{2}\right), 16.6\left(\mathrm{CH}_{2}\right), 16.2\left(\mathrm{CH}_{2}\right), 14.1(2$ $\times \mathrm{CH}_{3}$ Dpg). Anal. calcd for $\mathrm{C}_{33} \mathrm{H}_{47} \mathrm{~N}_{5} \mathrm{O}_{6}: \mathrm{C}: 65.00, \mathrm{H}: 7.77, \mathrm{~N}: 11.49$; found: C: 65.11, H: 7.79, $\mathrm{N}: 11.21$.

\subsection{Boc-Gly-Phe-Phe-Dbg-NH 2 (4)}

$\mathrm{Z}-\mathrm{Dbg}-\mathrm{OH}$. Following the procedure described for Z-Dpg-OH above, this compound was synthesized in a 15 mmolar scale. The reaction was carried out at $50{ }^{\circ} \mathrm{C}$ for four hours. After working up the reaction mixture an oil was obtained, which crystallized on standing. Yield $43 \%$, mp. 71-72 ${ }^{\circ} \mathrm{C} .{ }^{1} \mathrm{H}$ NMR (DMSO- $\left.d_{6}\right) \delta(\mathrm{ppm}): 0.80\left(2 \mathrm{~d}, 12 \mathrm{H}, \mathrm{J}=4.9 \mathrm{~Hz}, 4 \times \mathrm{CH}_{3}\right), 1.50(\mathrm{~m}, 2 \mathrm{H}, 2$ $\times \mathrm{CH}), 1.60\left(\mathrm{dd}, 2 \mathrm{H}, \mathrm{J}=6.7,13.8 \mathrm{~Hz}, \mathrm{CH}_{2}\right), 2.00\left(\mathrm{dd}, 2 \mathrm{H}, \mathrm{J}=5.5,13.8 \mathrm{~Hz}, \mathrm{CH}_{2}\right), 5.00(\mathrm{~s}, 2 \mathrm{H}$, $\left.\mathrm{CH}_{2} \mathrm{Ar}\right), 6.50(\mathrm{~s}, 1 \mathrm{H}, \mathrm{NH}), 7.30(\mathrm{~m}, 5 \mathrm{H}, \mathrm{Ar})$. Anal. calcd for $\mathrm{C}_{18} \mathrm{H}_{27} \mathrm{NO}_{4}: \mathrm{C}: 67.26, \mathrm{H}: 8.47, \mathrm{~N}$ : 4.36; found: C: $67.34, \mathrm{H}: 8.76, \mathrm{~N}: 4.49$.

$\mathrm{Z}-\mathrm{Dbg}-\mathrm{NH}_{2}$. General Method A was used to give the product in a yield of 75\%, mp. 129.5-130 ${ }^{\circ} \mathrm{C}$ (ethyl ether/light petroleum). ${ }^{1} \mathrm{H}$ NMR (DMSO- $\left.d_{6}\right) \delta(\mathrm{ppm}): 0.80(2 \mathrm{~d}, 12 \mathrm{H}, \mathrm{J}=5.2 \mathrm{~Hz}, 4 \times$ $\left.\mathrm{CH}_{3}\right), 1.40(\mathrm{~m}, 2 \mathrm{H}, 2 \times \mathrm{CH}), 1.58\left(\mathrm{dd}, 2 \mathrm{H}, \mathrm{J}=5.9,14.0 \mathrm{~Hz}, \mathrm{CH}_{2}\right), 2.10(\mathrm{dd}, 2 \mathrm{H}, \mathrm{J}=6.1,14.3 \mathrm{~Hz}$, 
$\left.\mathrm{CH}_{2}\right), 5.00\left(\mathrm{~s}, 2 \mathrm{H}, \mathrm{CH}_{2} \mathrm{Ar}\right), 6.50(\mathrm{~s}, 1 \mathrm{H}, \mathrm{NH}), 7.30(\mathrm{~m}, 5 \mathrm{H}, \mathrm{Ar}), 7.42$ and $7.60\left(2 \mathrm{~s}, 2 \mathrm{H}, \mathrm{NH}_{2}\right)$. Anal. calcd for $\mathrm{C}_{18} \mathrm{H}_{28} \mathrm{~N}_{2} \mathrm{O}_{3}$ : C: 67.47, H: 8.81, N: 8.74; found: C: 67.46, H: 8.85, N: 8.95.

$\mathrm{H}$-Dbg- $\mathrm{NH}_{2}, \mathrm{HBr}$. Following general Method $\mathrm{C}$, a solid compound was obtained, which was pure by tlc and used without further purification. Yield $98 \%$, mp. $205.7-206{ }^{\circ} \mathrm{C}$, and used without crystallization in the next step. ${ }^{1} \mathrm{H}$ NMR (DMSO- $\left.d_{6}\right) \delta(\mathrm{ppm}): 0.80$ (apparent t, $12 \mathrm{H}$, $\left.\mathrm{J}=6.4 \mathrm{~Hz}, 4 \times \mathrm{CH}_{3}\right), 1.40-1.80\left(\mathrm{~m}, 6 \mathrm{H}, 2 \times \mathrm{CH}+2 \times \mathrm{CH}_{2}\right), 7.60$ and $7.80\left(2 \mathrm{~s}, 2 \mathrm{H}, \mathrm{NH}_{2}\right), 7.9(\mathrm{br}$ s, $3 \mathrm{H}, \mathrm{NH}_{3}{ }^{+}$).

Boc-Phe-Dbg- $\mathrm{NH}_{2}$. General Method D was used to obtain the required product in a yield of 50\%, mp. 169.8-171 ${ }^{\circ} \mathrm{C}$ (ethyl acetate/light petroleum). ${ }^{1} \mathrm{H}$ NMR (DMSO- $\left.d_{6}\right) \delta(\mathrm{ppm}): 0.70-$ $0.80\left(\mathrm{~m}, 12 \mathrm{H}, 4 \times \mathrm{CH}_{3}\right), 1.30(\mathrm{~s}, 9 \mathrm{H}, \mathrm{Boc}), 1.50\left(\mathrm{~m}, 4 \mathrm{H}, 2 \times \mathrm{CH}_{2}\right), 2.30(\mathrm{~m}, 2 \mathrm{H}, 2 \times \mathrm{CH}), 2.70$ (dd, $1 \mathrm{H}, \mathrm{J}=3.4,14.0 \mathrm{~Hz}, \beta \mathrm{CH}_{2} \mathrm{Phe}$ ), 2.80-3.00 (m, $1 \mathrm{H}, \beta \mathrm{CH}_{2} \mathrm{Phe}$ ), 3.90 (m, $1 \mathrm{H}, \alpha \mathrm{CH}$ Phe), 7.30 (m, 5H, Ar), 7.40 and $7.60\left(2 \mathrm{~s}, 2 \mathrm{H}, \mathrm{NH}_{2}\right), 7.50$ (d, 1H, J=8.1 Hz, NH Phe), 7.90 (s, 1H, NH Dbg). Anal. calcd for $\mathrm{C}_{24} \mathrm{H}_{39} \mathrm{~N}_{3} \mathrm{O}_{4}$ : C: 66.48, H: 9.09, N: 9.69; found: C: 66.11, H: 9.02, N: 9.68.

H-Phe-Dbg-NH2,TFA. Following general Method B, 90 minutes after the reaction had been started a solid compound was obtained, which was pure by tlc and used without further purification. Yield 90\%, mp. $264{ }^{\circ} \mathrm{C}$ dec. ${ }^{1} \mathrm{H}$ NMR (DMSO-d $\left.{ }_{6}\right) \delta(\mathrm{ppm})$ : 0.70-0.80 (m, 12H, $4 \times$ $\left.\mathrm{CH}_{3}\right), 1.20(\mathrm{~m}, 1 \mathrm{H}, \mathrm{CH}), 1.55\left(\mathrm{~m}, 3 \mathrm{H}, \mathrm{CH}+\mathrm{CH}_{2}\right), 2.24\left(\mathrm{~m}, 2 \mathrm{H}, \mathrm{CH}_{2}\right), 2.85(\mathrm{dd}, 1 \mathrm{H}, \mathrm{J}=6.0,13.9$ $\mathrm{Hz}, \beta \mathrm{CH}_{2}$ Phe), 3.10 (m, 1H, $\beta \mathrm{CH}_{2}$ Phe), 4.40 (apparent t, 1H, J=6.0 Hz, $\alpha \mathrm{CH}$ Phe), 7.30 (m, $\left.6 \mathrm{H}, \mathrm{Ar}+\mathrm{NH}_{2}\right), 7.55\left(\mathrm{~s}, 1 \mathrm{H}, \mathrm{NH}_{2}\right), 8.00\left(\right.$ br s, $\left.3 \mathrm{H}, \mathrm{NH}_{3}{ }^{+}\right), 8.10(\mathrm{~s}, 1 \mathrm{H}, \mathrm{NH} \mathrm{Dbg})$. Anal. calcd for $\mathrm{C}_{21} \mathrm{H}_{32} \mathrm{~N}_{3} \mathrm{O}_{4} \mathrm{~F}_{3}$ : C: 56.38, H: 7.16, N: 9.40; found: C: $56.55, \mathrm{H}: 7.13, \mathrm{~N}: 9.50$.

Boc-Phe-Phe-Dbg- $\mathrm{NH}_{2}$. General Method E was used to obtain the required product in a yield of 67\%, mp. 93.2-95.4 ${ }^{\circ} \mathrm{C}$ (ethyl acetate/light petroleum). ${ }^{1} \mathrm{H}$ NMR (DMSO- $d_{6}$ ) $\delta$ (ppm): 0.70-0.80 (m, 12H, $\left.4 \times \mathrm{CH}_{3}\right), 1.25$ (s, 9H, Boc), $1.50\left(\mathrm{~m}, 4 \mathrm{H}, 2 \times \mathrm{CH}+\mathrm{CH}_{2}\right), 2.30\left(\mathrm{~m}, 2 \mathrm{H}, \mathrm{CH}_{2}\right), 2.60-$ 2.90 (m, $2 \mathrm{H}, \beta \mathrm{CH}_{2}$ Phe), 3.00-3.20 (m, 2H, $\beta \mathrm{CH}_{2}$ Phe), 4.20 (m, $1 \mathrm{H}, \alpha \mathrm{CH}$ Phe1), 4.40 (m, $1 \mathrm{H}$, $\alpha \mathrm{CH}$ Phe), 6.85 (d, 1H, J=8.8 Hz, NH Phe), 7.20 (m, 10H, Ar), 7.40 and 7.55 (2s, 2H, NH $_{2}$, 7.80 (s, 1H, NH Dbg), 8.60 (d, $1 \mathrm{H}, \mathrm{J}=8.2 \mathrm{~Hz}, \mathrm{NH}$ Phe). Anal. calcd for $\mathrm{C}_{33} \mathrm{H}_{48} \mathrm{~N}_{4} \mathrm{O}_{5}: \mathrm{C}: 68.24$, H: 8.33, N: 9.65; found: C: 68.14, H: 8.25, N: 9.64.

H-Phe-Phe-Dbg- $\mathrm{NH}_{2}$,TFA. Following general Method B, 90 minutes after the reaction had been started a solid compound was obtained, which was pure by tlc and used without further purification. Yield 53\%, mp. 119-121 ${ }^{\circ} \mathrm{C} .{ }^{1} \mathrm{H}$ NMR (DMSO- $\left.d_{6}\right) \delta(\mathrm{ppm}): 0.70-0.80(\mathrm{~m}, 12 \mathrm{H}, 4 \times$ $\left.\mathrm{CH}_{3}\right), 1.30(\mathrm{~m}, 1 \mathrm{H}, \mathrm{CH}), 1.50\left(\mathrm{~m}, 3 \mathrm{H}, \mathrm{CH}+\mathrm{CH}_{2}\right), 2.30\left(\mathrm{~m}, 2 \mathrm{H}, \mathrm{CH}_{2}\right), 2.80\left(\mathrm{~m}, 2 \mathrm{H}, \beta_{\mathrm{CH}} \mathrm{Phe}_{2}\right.$, 
3.15 (m, 2H, $\beta \mathrm{CH}_{2}$ Phe), 3.95 (m, 1H, $\alpha \mathrm{CH}$ Phe), 4.50 (m, 1H, $\alpha \mathrm{CH}$ Phe), 7.30 (m, 10H, Ar), 7.45 and $7.60\left(2 \mathrm{~s}, 2 \mathrm{H}, \mathrm{NH}_{2}\right), 7.80(\mathrm{~s}, 1 \mathrm{H}, \mathrm{NH} \mathrm{Dbg}), 8.00\left(\right.$ br s, $\left.3 \mathrm{H}, \mathrm{NH}_{3}{ }^{+}\right), 9.20(\mathrm{~d}, 1 \mathrm{H}, \mathrm{J}=8.2$ $\mathrm{Hz}, \mathrm{NH} \mathrm{Phe})$.

Boc-Gly-Phe-Phe-Dbg- $\mathrm{NH}_{2}$. General Method E was used to obtain the final product, requiring no further purification in a yield of $98 \%, \mathrm{mp} .144-146{ }^{\circ} \mathrm{C} .{ }^{1} \mathrm{H}$ NMR (DMSO- $\left.d_{6}\right) \delta(\mathrm{ppm})$ : 0.70$0.80\left(\mathrm{~m}, 12 \mathrm{H}, 4 \times \mathrm{CH}_{3}\right), 1.30(\mathrm{~m}, 10 \mathrm{H}, \mathrm{Boc}+\mathrm{CH}), 1.50\left(\mathrm{~m}, 3 \mathrm{H}, \mathrm{CH}+\mathrm{CH}_{2}\right), 2.30\left(\mathrm{~m}, 2 \mathrm{H}, \mathrm{CH}_{2}\right)$, 2.60-2.80 (m, $2 \mathrm{H}, \beta_{\mathrm{CH}}$ Phe), 3.10 (m, $2 \mathrm{H}, \beta \mathrm{CH}_{2} \mathrm{Phe}$ ), 3.30-3.50 (m, 2H, $\mathrm{CH}_{2}$ Gly), 4.40 (m, 1H, $\alpha \mathrm{CH} \mathrm{Phe}^{2}$ ), 4.50 (m, 1H, $\alpha \mathrm{CH} \mathrm{Phe}^{1}$ ), 6.78 (t, 1H, J=6.3 Hz, NH Gly), 7.20 (m, 10H, Ar), 7.48 and 7.62 (2s, 2H, NH $\left.H_{2}\right), 7.85(\mathrm{~s}, 1 \mathrm{H}, \mathrm{NH} \mathrm{Dbg}), 7.99$ (d, 1H, J=8.7 Hz, NH Phe $\left.{ }^{1}\right), 8.86(\mathrm{~d}$, $1 \mathrm{H}, \mathrm{J}=8.1 \mathrm{~Hz}, \mathrm{NH} \mathrm{Phe}^{2}$ ). ${ }^{13} \mathrm{C}$ NMR (DMSO-d $) \delta(\mathrm{ppm}): 175.6$ (CO Dbg), $171.5\left(C \mathrm{O} \mathrm{Phe}{ }^{1}\right.$ ), 168.9 (CO Phe ${ }^{2}$ ), 168.7 (CO Gly), 155.6 (CO Boc), 138.1 (C Ar), 138.0 (C Ar), 129.2 (2 × CH Ar $), 128.9(2 \times \mathrm{CH} \mathrm{Ar}), 128.2(2 \times \mathrm{CH} \mathrm{Ar}), 127.9(2 \times \mathrm{CH} \mathrm{Ar}), 126.2(2 \times \mathrm{CH} \mathrm{Ar}), 77.9(\mathrm{C}$

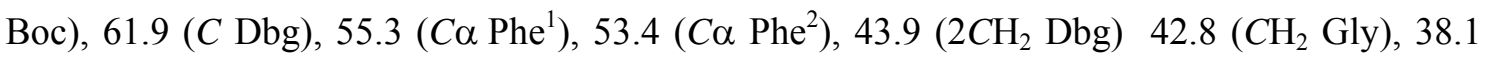
( $\left.\beta \mathrm{CH}_{2} \mathrm{Phe}\right), 36.8\left(\beta_{\mathrm{CH}} \mathrm{Phe}\right), 28.2\left(3 \times \mathrm{CH}_{3} \mathrm{Boc}+\mathrm{CH}\right), 24.1\left(\mathrm{CH}_{3} \mathrm{Dbg}\right)$, , $24.0\left(\mathrm{CH}_{3} \mathrm{Dbg}\right)$, $23.9(\mathrm{CH} \mathrm{Dbg}), 23.1\left(\mathrm{CH}_{3} \mathrm{Dbg}\right), 22.7\left(\mathrm{CH}_{3} \mathrm{Dbg}\right)$. Anal. calcd. for $\mathrm{C}_{35} \mathrm{H}_{51} \mathrm{~N}_{5} \mathrm{O}_{6}: \mathrm{C}: 65.91, \mathrm{H}$ : 8.06, N: 10.98; found: C: $65.86, \mathrm{H}: 8.29, \mathrm{~N}: 10.75$.

\section{Acknowledgements}

We wish to acknowledge Dr. Sílvia M.A. Pereira-Lima for the preparation of amino acids HDpg-OH and H-Dbg-OH, Miss Elisa Pinto for running the NMR experiments and for the elemental analyses, and Mr. Nuno Cerqueira for help with molecular modeling. We also wish to acknowledge the Fundação para a Ciência e a Tecnologia for financial support to the Instituto de Biotecnologia e Química Fina (University of Minho).

\section{References}

1. Lombard, A.; Simone, G.; Galdiero, S.; Nastri, F.; Costanzo, L.; Makihira, K.; Yamada, T.; Pavone, V. Biopolymers 2000, 53, 150-160, and references cited therein.

2. Angela Lombardi, giuseppina De Simone, Stefania Galdiero, Lombard, A.; Simone, G.; Galdiero, S.; Nastri, F.; Costanzo, L.; Makihira, K.; Yamada, T.; Pavone, V. Biopolymers 2000, 53, 182-188, and references cited therein.

3. Benedetti, E.; Isernia, C.; Nastri, F.; Pedone, C.; Saviano, M.; Mierke, D.; Melchiorri, P.; Negri, L.; Potenza, R.; Severini, C.; Erspamer, V. Eur. J. Org. Chem. 1998, 2279-2287.

4. Horikawa, M.; Shigeri, Y.; Yumoto, N.; Yoshikawa, S.; Nakajima T.; Ohfune, Y. Bioorg. Med. Chem. Lett. 1998, 8, 2027-2032, and references cited therein.

5. Halab, L.; Bélec L.; Lubell, W. Tetrahedron 2001 57, 6439-6446, and references cited therein.

6. Karle, I.; Balaram, P. Biochemistry 1990, 29, 6747-6756.

7. Benedetti, E.; Toniolo, C.; Hardy, P.; Barone, V.; Bavoso, A.; Grimaldi, P.; Lelj, F.; Pavone, V.; Pedone, C.; Bonora, G.; Lingham, I. J. Am. Chem. Soc. 1984, 106, 8146-8152. 
8. Benedetti, E. Biopolymers 1996, 40, 3-44.

9. Blasio, B.; Pavone, V.; Saviano, M.; Lombardi, A.; Nastri, F.; Pedone, C.; Benedetti, E.; Crisma, M.; Anzolin M.; Toniolo, C. J. Am. Chem. Soc. 1992, 114 (16), 6273-6278.

10. Crisma, M.; Valle, J.; Toniolo, C.; Rao, R.; Prasad, S.; Balaram, P. Biopolymers 1995, 35, 1-9.

11. Benedetti, E.; Barone, V.; Bavoso A.; Di Blasio, B.; Lelj, F.; Pavone, V.; Pedone, C.; Bonora G.; Toniolo C.; Leplawy M.; Kaczmarek K.; Redlinski A. Biopolymers 1988, 27, 357-371.

12. Kaul, R.; Banumathi, S.; Velmuragan, D.; Ravikumar, K.; R. Balaji R.; Balaram, P. J. Peptide Res. 2000, 55, 271-278.

13. Brandenburg, D. Experimental and Clinical Endocrinology \& Diabetes 1999, 107 (Suppl. 2), S6-S11.

14. Costa, S.; Maia H.; Pereira-Lima, S. Org. Biomol. Chem. 2003, 1, 1475-1479.

15. Spencer, J.; Antonenko, V.; Delaet N.; Goodman, M. Int. J. Peptide Protein Res. 1992, 40, 282-293.

16. Coste, J.; Frérot, E.; Jouin, P. J. Org. Chem. 1994, 59, 2437-2446.

17. Gross, E.; Meinhofer, J. "The Peptides. Synthesis, Analysis, Biology" Vol.1, Academic Press, London, 1979, p. 256-58.

18. Akaji,K.; Kuriyama N.; Kiso,Y. Tetrahedron Lett. 1994, 35 (20), 3315-3318.

19. Fu Y.; Hammer, R. Organic Letters 2002, 4 (2), 237-240 and references cited therein.

20. Chen, S.-T.; Wu, S.-H.; Wang, K.-T. Synthesis Communic. 1989, 37-38.

21. Ludvigsen, S.; Andersen K.; Poulsen, F. J. Mol. Biol. 1991, 731-736.

22. Stachel, S.; Hu, H.; Van, Q.; Shaka A.; Van Vranken, D. Bioorg. Med. Chem. 1998, 6, 1439-1446.

23. Paradisi, M.; Torrini, I.; Zecchini, G.; Lucente, G.; Gavuzzo, E.; Mazza, F.; Pochetti, G. Tetrahedron. 1995, 51, 2379-2386, and references cited therein.

24. Bodansky, M.; Bodansky, A. "The Practice of Peptide Synthesis", Springer-Verlag, Berlim, 1984, p.20.

25. Pettit, G. "Synthetic Peptides", Vol.3, Academic Press, London, 1975. 